\title{
STRUCTURE AND QUR'ANIC INTERPRETATION: A STUDY OF SYMMETRY AND COHERENCE IN ISLAM'S HOLY TEXT
}

Ersin $K A B A K C I^{1}$

Raymond F. (2014) Structure and Qur'anic Interpretation: A Study of Symmetry and Coherence in Islam's Holy Text, White Cloud Press, Ashland, Oregon 163 p. (ISBN 978-1-935952-98-5)

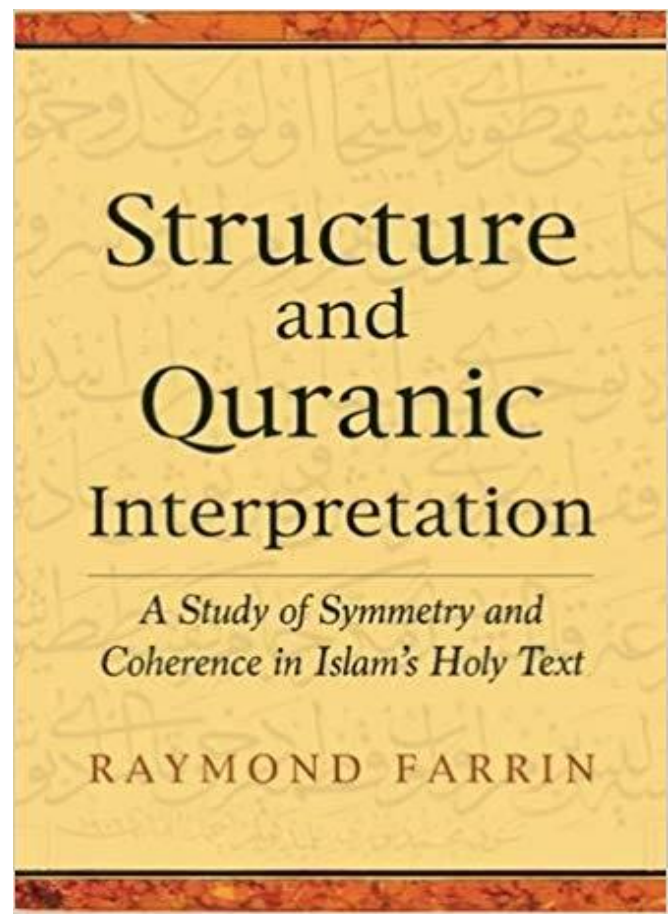

Raymond Farrin, associate professor of Arabic at the Department of Arabic and Foreign Languages at American University of Kuwait, studied Arabic in Cairo and received a PhD in Near Eastern Studies from University of California, Berkeley. He has another book Abundance from the Desert: Classical Arabic Poetry (2011) and several articles two of which are Surat al-Baqara: A Structural Analysis (2010) and Surat al-Nisa and the Centrality of Justice (2016).

His work to be introduced here is the most prominent one especially in the context of the studies searching for the unity in the Qur'anic text. The book consists of an introduction, six main chapters, a conclusion, three Appendixes and a reading group guide.

Farrin introduces his book by taking attention to the very long history of the subject of 'the structure of the Qur'an'. Considering the Islamic literature, it goes back to the 3rd century of hijrî (p. xi). While in the classical era, the studies on the coherence of the

Qur'anic text shows an atomistic (verse-by-verse) character (p. xi-xii); the 20th century exegetes such as Abd al-Hamid al-Farahi (d. 1930), Amin Islahi (d. 1997), Muhammad al-Tabatabai (d. 1966) and Sayyid Qutb (d. 1966) approached the suras holistically (p. xiv). As for the western literature, till 1980s, the Qur'an was regarded as a very "incoherent" text and it was "baffling" the reader (xiii). However after 1980s, several muslim and nonmuslim scholars such as Angelika Neuwirth, Pierre Crapon de Caprona, Mustansir Mir, Muhammad Abdel Haleem, Matthias Zahniser, Neal Robinson, Carl Ernst and Michel Cuypers in the Western Academia began to claim that the Qur'anic text has a remarkable unity $(\mathrm{xv})$.

Farrin especially takes attention to the rhetorical analysis of the Qur'an applied by Michel Cuypers. In the very beginning, he shows the symmetry types that were shared by Cuypers in his works and takes this kind of analysis as a principal model for his study. Another scholar guiding his analysis is Amin Islahi who claims that most of the suras in the Qur'an form pairs. In addition

${ }^{1}$ Arş.Gör., İlahiyat Fakültesi Temel İslam Bilimleri, ersinkabakci@hitit.edu.tr 
to these two scholars, Mary Douglas with Thinking in Circles: An Essay on Ring Composition (2007) also contributed to Farrin in the context of the subject of concentric symmetry. Farrin's main claim in this work, unlike the criticism of "disjointedness" in the Qur'an, is to show the integral unity of the Qur'anic text, from its suras to the whole text. (xv-xvi).

In the first chapter, Framing the Qur'an, the author analyzes the first sura of the Qur'anic text, al-Fatiha which 'epitomizes the Qur'an in terms of structure and theme' (p. 1). Farrin does not count the invocation (basmala) as a verse for it does not contribute the structure of the sura (p. 3). This is a notable example showing how the author gives precedence the structural coherence.

In thematic analysis of the sura, two points take the reader's attention. The first one is that the author extends the boundaries of the sura and he links verses with the ones from another sura. Interestingly, Farrin contacts the 'first' verse of the 'text' with the 'Last' day. To put it more explicitly, the book begins with 'Praise be to God, Lord of all peoples' (1: 1) and in the day of judgment, the same sound is heard: 'Praise be to God, Lord of all peoples' (Q 39: 75). Thus, a combination of the structural and thematic elements gives a nice example of 'coherence' (3-4). On the other hand, it creates confusion about the 'boundaries' of the search for coherence.

The second point about the analysis of the sura al-Fatiha is the references to the historical datum from Islamic literature. Farrin mentions a tradition of Ibn Abbas explaining the meaning of al'alamin which means "humankind and jinn". The author uses this reference to show the overall unity of the Qur'anic text. The book begins with the praise to the Lord of al-alamin (Q 1: 1) namely, humankind and jinn and it ends with the verse seeking refuge to the Lord of people from "humankind and jinn" (Q 114: 6). (p. 8). This link really attracts the reader; on the other hand there appears a question accompanying it: Do we have right to use history pragmatically to construct coherence in the text? In other words, what is the place of the historical datum in the search for the unity in the Qur'anic text?

In the following lines, Farrin shows the "rings" of the sura and the concentric structure in it. He finishes the chapter by taking attention the integral coherence of the Qur'anic text: The Qur'an begins with a prayer (Q: 1), in the body of the Qur'an we witness an answer to the prayer (Q 2: 112) and ends with a prayer (Q 114) (p. 8) So, what is claimed here then that the first sura of the Qur'an has unity in itself and it has its right place considering the whole text.

The second chapter, The Chapter as Unity discusses the idea that each sura in itself has a thematic and structural unity and this argument is exemplified with the longest sura of the Qur'an, Sura al-Baqara. Giving brief explanations about the background of the sura, Farrin shares the concentric structure of the seven sections each of which has its own parts (p. 10).

Now, let's focus our attention to some impressions on the analysis of the sura al Baqara. First of all, in almost all sections, we witness references to Tafsir tradition. The analysis is strengthened with the citations of such exegetes as Tabari, Qurtubi, Suyuti, Zarkashi, Zamakhshari (9-21). This shows that although Farrin makes a special reference to the approach of the rhetorical analysis of Cuypers, which can be regarded as, at least to a large extend, text-centered approach, he includes the historical datum to his analysis to support the symmetrical structure of the text. Again, we should note that while rhetorical analysis has its own objective rules, adding historical sources to the analysis arises a question: To what extent does an author of rhetorical analysis have right to use historical datum in his study? On what grounds would the author disregard the historical datum contrasting his symmetrical construction?

Another subject is the alleged concentric composition (A/B/C/D/C'/B'/A') of the sura. The author 
attributes a great significance to this structure because the centers of the concentric symmetries bear the main message of the text. In this context, Farrin puts ' $D$ ' section to the center. Here the prayer direction for Muslims change and even if this is a junction, the larger perspective is given in the middle of this section (v. 147-148): "The truth is from your Lord, so never be among the doubters. Every community has its own direction; so compete with each other in doing good works. Wherever you are, God will bring you together." Farrin links these verses with Q 5: 48 in which, according to him, (religious) pluralism is emphasized. (p. 15). The alleged religious pluralism emphasis in the Qur'anic text is shared by Cuypers and the consistency analysis of this argument is still being studied by the writer of this review. For the time being let's raise a question: There are several verses about the other 'monotheist' religions in the Qur'an and we come across several criticism on them. So, if the Qur'an is a 'coherent' text, how would we read the verses criticizing the other religions and the ones emphasizing plurality in consistent way together? Are all the verses having problem with the other monotheist religions in the 'frames' of the text? Can we claim it with reference to the 'limited' concentric structures available in certain suras?

The third chapter discusses that the suras form pairs. Farrin refers to Islahi, as he is the scholar bringing this subject into agenda. According to Islahi two independent adjacent suras have thematic and structural correspondences to each other (p. 22). In this context, Farrin analyzes the suras 113 and 114 as short ones (p. 23-24) and the suras 2 and 3 as a long pair (p. 24-32). It's notable that some correspondences, though in different manners, are discovered both in the classical and modern period. Both sura pairs, according to the author, correspond to each other both thematically and structurally. In the long pair, Farrin, again, stresses that the text 'calls to unity' (p. 28, 32).

Chapter four, after short and long pairs exemplified in the previous one, introduces a mediumlength pair (Q 12-13). Each sura is divided into parts and the concentric symmetry of the suras is given as a diagram (p. 43-45). In these suras Farrin underlines the universal message that all people believing God and doing good works will deserve salvation (p. 46).

Chapter five mentions sura groups which, according to Farrin, is "the third major principle evident in the organization of the Qur'an.” (p. 48). The groups consist of suras from three to ten (average is 6). The suras in a group have the same concentrism and parallelism.

Farrin, after mentioning sura groups, takes the subject a step further and claims that the groups are ordered as well. Nineteen groups form two concentric 'systems' each of which also is composed of nine groups. The sura remained forms an independent group in the center (p. 50-58).

In the final chapter, The Central Group, seven medium-length suras in the middle of the Qur'an (Q 50-56) are analyzed. According to Farrin, the group has a universal theme: Resurrection, Judgment, the Garden and the Fire (p. 59). Interestingly, Farrin links these seven suras with the verse Q 15: 87: "We have brought you seven of the mathani [doubled ones] and the Glorious Qur'an." The author argues that this 'seven' of the mathani is a reference to the 'seven central chapters', that is, Q 50-56 (p. 59).

In the conclusion part, Farrin stresses that the Qur'an has a perfect structural and thematic unity. As for the 'writer' of the text, the most probable scenario is that the prophet arranged the whole text (p. 70). Whether or not it is arranged by divine direction is 'a question of faith' (p. 74).

Appendix A consists of structural summaries of the suras 2, 3, 12, 13, 50, 51, 52, 53 and 56 (7599). Appendix B includes the correspondences of all the sura pairs except the following ones: 43- 
44, 45-46, 47-48 and 63-64 (100-113). Appendix C shares the links of the sura groups except the ones discussed throughout the book (p. 114-121). In Reading Group Guide, Farrin advises some discussion topics in the context of the search for the unity in the Qur'anic text (122-128).

The studies on the search for the unity in the Qur'anic text are highly dynamic and abundant in the contemporary Western academia. In company with different kinds of approaches, the structural, thematic, formal aspects of the Qur'anic text as well as its rhetoric are studied. In this context, Farrin scrutinizes the structure of the Qur'an considering its rhetoric, historical background of the suras, thematic and structural elements of the text from its suras to sura pairs, sura groups to systems. In sum, Structure and Qur'anic Interpretation: A Study of Symmetry and Coherence in Islam's Holy Text is an invaluable work waiting curious readers wondering the structure of the Qur'anic Text. 